\title{
George Frisbie Ryan
}

Dr. George Frisbie Ryan lost a valiant battle with cancer on 25 Jan. 2004 in Tacoma, Wash. His character was a rare blend of a brilliant mind and a gentle heart and he will be greatly missed by his family and friends. George was born 28 July 1921, in Yakima, Wash., to James Percy and Nina Frisbie Ryan. He grew up on the family fruit ranch in the sagebrush hills northwest of Wapato, Wash. He attended Yakima Junior College before entering Washington State College (WSC) in 1940. His education was interrupted by World War II when he entered the Army Air Corps in September 1942. He served as an instructor on flight simulators. He reached the rank of Sergeant and was honorably discharged in February 1946. He then returned to WSC and completed his BS in 1947. He married Beverly Rifle of Covington, Kent., the same year. George continued his education at UCLA where he received his $\mathrm{PhD}$ in horticulture. He taught there until 1961. His only child, Bruce Douglas Ryan, was born in Los Angeles in 1950. From 1961 to 1966 , George was a research horticulturist at the University of Florida Citrus Experiment Station at Lake Alfred. In 1967, George and his family returned to his native Washington where he accepted the position of weed scientist at the WSU Experiment Station at Puyallup. His research was mainly concerned with weed control and plant growth regulators in horticultural crops. He was recognized for his outstanding research with a myriad of weed-control problems in ornamental plant production nurseries and highway landscapes. $\mathrm{He}$ made major contributions to the national TR-4Program. He was also widely known as the first to report Triazine resistance in common groundsel (Senecio vulgaris L.). George was a member of WSSA and ASHS. Following his retirement in 1983 he continued his involvement with the Rhododendron Species Foundation, which had begun before the 1973 planting of the original study garden. He also worked with others from the Rhododendron Society in developing the rhododendron garden in Point Defiance Park.

George was an avid hiker in the mountains of the Pacific Northwest. His son Bruce often accompanied him in this endeavor. Bruce passed away 22 Jan. 2004 in Tempe. Ariz. He was a research scientist and associate curator for the Lichen Herbarium at Arizona State University, where he had received his $\mathrm{PhD}$. George is survived by his wife Beverly, his brother Jim and his wife Betty, a niece Sally Ryan Hoy, and nephews Roger Ryan, Steve Granholm, and Dean Granholm and their families. 